\title{
Measuring and Benchmarking Corporate Environmental Performance
}

\author{
Marie Pavláková Dočekalová, Alena Kocmanová, and Jana Hornungová \\ University of Technology, Faculty of Business and Management, Brno, Czech Republic \\ \{docekalova, kocmanova, hornungova\} @fbm. vutbr.cz
}

\begin{abstract}
Corporate environmental performance is discussed in this paper. The aim of the paper is to propose a framework for an environmental performance benchmarking model. Corporate environmental performance is measured by key performance indicators (KPIs): Emissions of Greenhouse Gases, Water Consumption, Waste Production and Gross Value Added. Performance is benchmarked against the production frontier estimated by Data Envelopment Analysis. The environmental performance benchmarking model was created and tested on real corporate data. The model determines relative corporate environmental performance, identifies weaknesses in performance and quantifies performance gaps.
\end{abstract}

Keywords: corporate environmental performance, benchmarking, data envelopment analysis.

\section{Introduction}

Reporting corporate environmental performance is now commonplace among large enterprises. Twenty years ago, it was performed by just a few pioneers, and in the Czech Republic, for example, it can be said with little exaggeration that no companies informed their stakeholders about their environmental performance. In April 2014, the European Parliament adopted a directive that introduces the obligation that companies with more than 500 employees report on their social responsibility and, therefore, the impact of their business activities on the environment. Corporate environmental performance directly affects many corporate stakeholders - employees, consumers, the community, government bodies, etc. These stakeholders create a demand for clear and relevant information to support their decision-making. Traditional performance evaluation systems do not reflect the requirements of corporate stakeholders. The aim of this paper is to integrate the measuring of corporate environmental performance into performance measurement systems by proposing a framework for an environmental performance benchmarking model.

\section{A Theoretical Approach to Environmental Performance}

Corporate environmental performance is defined as the impact of the company on the environment. A company's influence on the environment is assessed in terms of 
harmful activities affecting the environment [1]. ISO 14031 defines environmental performance evaluation as a "process to facilitate management decisions regarding an organization's environmental performance by selecting indicators, collecting and analyzing data, assessing information about environmental performance, reporting and communicating, and periodically reviewing and improving this process" [2].

There has been a great debate about the relationship between corporate environmental performance and economic performance. Both positive and negative statements can be found in scientific publications. The authors in [3] concluded that environmental and economic corporate performance are positively linked and that industry growth moderates the relationship, with the returns in environmental performance being higher in high-growth industries. The authors in $[4,5,6]$ state that economic benefits are attained by the use of brands and advertisements providing information about the sustainability of products, thereby supporting product differentiation. On the other hand, a meta-analysis focusing on 37 empirical studies examining the relationship between environmental and economic performance shows that the results remain ambiguous despite three decades of theoretical and empirical research [7].

\subsection{Environmental Benchmarking}

Benchmarking represents a way of finding quality and achieving success on the basis of organic growth. The approach taken by companies to environmental benchmarking is influenced by the regulatory context, company strategy, product type, corporate and national culture, resource costs and stakeholder demands [8]. According to [8], environmental benchmarking can be split into four categories: regulatory, gross emissions, efficiency and life cycle.

The principle of benchmarking is included in the ISO 14000 standards relating to environmental management. The process of implementing environmental benchmarking based on the ISO 14001 EMS standard is described in, for example, [9]. Corporate environmental performance is benchmarked against:

- the organization's environmental policy,

- environmental objectives,

- environmental targets, or

- other environmental performance requirements [10].

The Best Available Techniques (BAT) can also be used as a benchmark for environmental benchmarking [11]. At the EU level, BAT for selected industrial and agricultural activities are defined and quantified in Best Available Techniques Reference Documents (BREF).

The use of the following factors is an extremely common approach in setting benchmarks:

- the average value in an industry,

- the best-performing company in an industry,

- the value of the previous period. 
Performance can also be measured against the production frontier. Data Envelopment Analysis (DEA) and Stochastic Frontier Analysis (SFA) are methods that can be used for the purposes of estimating the production frontier. SFA has been defined by the authors $[12,13]$. SFA is based on the estimation of a stochastic frontier production function by econometric methods. DEA has been defined by the authors [14] and is based on the estimation of a production function by techniques of linear programming. The DEA method was used for performance evaluation and benchmarking by, for example, $[15,16]$.

\section{Methodology}

An environmental performance benchmarking model was created and tested on real corporate data. The given data was taken from large Czech manufacturing companies for the year 2012. This industry was chosen because manufacturing companies exert a significant impact on the environment. The sample is described in Table 1.

Table 1. Research sample( $\mathrm{N}$ - number of companies, \% - percentage in the sample)

\begin{tabular}{lrr}
\hline Criterion & $\boldsymbol{N}$ & $\boldsymbol{\%}$ \\
\hline Number of employees & & \\
250-500 & 10 & 55.5 \\
$501-1000$ & 3 & 16.7 \\
1001-2000 & 2 & 11.1 \\
above 2000 & 3 & 16.7 \\
Sector (as consistent with CZ-NACE) & 3 & \\
20. Manufacture of chemicals and chemical products & 3 & 16.7 \\
24. Manufacture of basic metals & 7 & 38.7 \\
25. Manufacture of fabricated metal products & 2 & 11.1 \\
27. Manufacture of electrical equipment & 3 & 16.7 \\
28. Manufacture of machinery and equipment n.e.c. & & \\
Legal form & 11 & 61.1 \\
Joint-stock company & 7 & 38.9 \\
Limited company & & \\
\hline
\end{tabular}

The first step in creating a corporate performance measurement system is identifying relevant key performance indicators (KPIs). Environmental KPIs are often nonfinancial metrics. Mathematical and statistical methods were used to determine the environmental performance indicators. For a detailed description of the construction of environmental KPIs see [17, 18, 19].

Originally, the set of environmental KPIs consisted of seven variables: Environmental Non-investment Costs, Air Emissions, Emissions of Greenhouse Gases, Energy Consumption, Water Consumption, Waste Production and Hazardous Waste Production.

The first step in data processing was a quality check carried out in order to find out whether there were any erroneous or missing data. The following statistic measures 
were computed in order to obtain a basic knowledge of performance indicators: mean, range, standard deviation and variance. A correlation analysis was performed in order to understand the relationship between the variables. High values of pair correlation coefficients, i.e. $|r|>0.8$, suggest multicollinearity. The variance inflation factor (VIF) was also used to detect multicollinearity. The VIF can be detected from an inversion matrix of the correlation matrix. Redundant KPIs were removed from the model. The reduced set of environmental KPIs then contained: Emissions of Greenhouse Gases, Water Consumption and Waste Production.

In this paper corporate performance is benchmarked against the production frontier - efficient frontier, which is constructed by efficient companies. The production frontier is estimated by Data Envelopment Analysis (DEA). The DEA method potential consists of identifying the best practice in the industry. The DEA model is based on assessing the quantity of consumed inputs by the produced outputs and estimation of the production possibility frontier. Three environmental KPIs (Emissions of Greenhouse Gases, Water Consumption and Waste Production) are considered as inputs. The goal of every business is to minimize values of these KPIs. Gross Value Added (GVA) is considered an output. GVA is the difference between the total production of goods and services and consumption (the value of goods and services consumed in production) - this approach is taken from the Eco Management and Audit Scheme (EMAS III). An input-oriented model with constant returns to scale (CCR model) is computed. The mathematical background of the model is described in [14].

The mathematical model of the primary input-oriented CCR model:

$$
\begin{gathered}
\max z=\sum_{i}^{r} u_{i} y_{i q} \\
\text { on conditions: } \sum_{i}^{r} u_{i} y_{i q} \leq \sum_{j}^{m} v_{j} x_{j k}, \sum_{j}^{m} v_{j} x_{j q}=1, u_{i} \geq \varepsilon, v_{j} \geq \varepsilon .
\end{gathered}
$$

Where $z$ is the coefficient of the technical efficiency of a company $C_{q} . u_{i}$ and $v_{j}$ are individual weights assigned so as to maximize efficiency and $\varepsilon$ is an infinitesimal constant that ensures that all weights of inputs and outputs are positive.

The professional optimization program Frontier Analyst from the company Banxia Software, which is very user friendly, was used for the model. The simplest method from the viewpoint of demands on software is the computation of DEA models with the use of MS Excel or using programmed applications such as DEA-Excel by Professor Jablonský and DEA Excel Solver by Professor Zhu. The specialized optimization software Lingo developed by the company Lindo Systems uses a special modelling language for notation. The model can also be imported into the program in MPS format. MPL for Windows from the company Maximal Software is an open optimization system. 


\section{$4 \quad$ Results and Discussion}

Figure 1 shows an environmental performance measurement system based on a benchmarking model. An environmental performance measurement system must be part of a corporate performance measurement system. In order to provide the whole picture about corporate performance, the corporate performance measurement system must also consider the social dimension in addition to the environmental and economic dimension. A balance between these three factors of corporate performance creates a triple-bottom-line and brings sustainability to organizations [20, 21, 22].

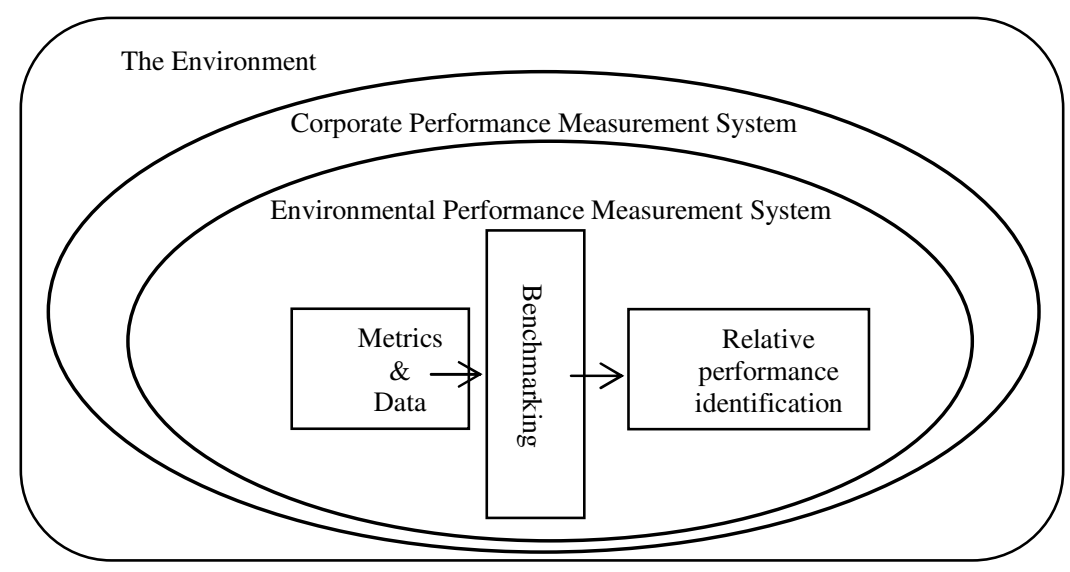

Fig. 1. Environmental performance measurement system

Metrics (environmental KPIs) and their values (data) are entered into the environmental performance benchmarking model. The outputs of the model are identification of:

- relative corporate performance and benchmarks,

- the best practice in the group of analyzed companies.

Table 2 presents the relative performance of all companies in the group given by the coefficient of technical efficiency derived from the DEA model. Performance is relative because it expresses the efficiency of the company within the studied group of companies. If it is equal to $100 \%$, this means that there is no company in the group that has a better performance. If the value is less than $100 \%$, there is at least one other company which is more effective. Both absolute and relative potential improvements are part of the output of the DEA model calculations. Table 2 gives relative potential improvements. The best-performing companies are " $\mathrm{A}$ ", " $\mathrm{G}$ " and " $\mathrm{Q}$ ". These efficient companies are referred to as "peer companies" and determine the efficiency frontier, i.e. they use the minimum quantity of inputs to produce the same quantity of outputs. 
Table 2. Corporate Performance - results of the environmental performance benchmarking model

\begin{tabular}{crrrr}
\hline Company & $\begin{array}{r}\text { Relative per- } \\
\text { formance (\%) }\end{array}$ & $\begin{array}{r}\text { Potential improvement (\%) } \\
\text { Emissions of } \\
\text { Greenhouse Gases }\end{array}$ & $\begin{array}{r}\text { Water Con- } \\
\text { sumption }\end{array}$ & $\begin{array}{r}\text { Waste Pro- } \\
\text { duction }\end{array}$ \\
\hline A & 100.00 & 0.0 & 0.0 & 0.0 \\
B & 27.16 & -99.9 & -72.8 & -83.0 \\
C & 3.9 & -96.9 & -99.7 & -96.9 \\
D & 1.41 & -98.6 & -100.0 & -98.6 \\
E & 1.00 & -99.0 & -99.7 & -99.0 \\
F & 2.00 & -98.0 & -99.1 & -99.5 \\
G & 100.00 & 0.0 & 0.0 & 0.0 \\
H & $\mathbf{6 9 . 3 6}$ & $-\mathbf{3 0 . 6}$ & $\mathbf{- 5 4 . 5}$ & $\mathbf{- 3 0 . 6}$ \\
I & 30.71 & -69.3 & -85.0 & -69.3 \\
J & 11.88 & -89.0 & -88.1 & -88.1 \\
K & 10.56 & -100.0 & -89.4 & -97.3 \\
L & 90.43 & -9.6 & -67.2 & -9.6 \\
M & 4.78 & -100.0 & -95.2 & -98.7 \\
N & 7.28 & -100.0 & -92.7 & -96.7 \\
O & 7.53 & -100.0 & -92.5 & -92.5 \\
P & 50.54 & -49.5 & -87.4 & -49.5 \\
Q & 100.00 & 0.0 & 0.0 & 0.0 \\
R & 30.12 & -69.9 & -97.7 & -69.9 \\
\hline
\end{tabular}

Let us analyze the performance of company " $\mathrm{H}$ " further. This company is not effective from the viewpoint of environmental KPIs per Gross Value Added. Table 3 gives the benchmarks for the environmental KPIs that will make sure that the company " $\mathrm{H}$ " becomes effective at the current level of Gross Value Added which is 378,433 thousand CZK.

Table 3. Environmental performance of company " $\mathrm{H}$ "

\begin{tabular}{lrrr}
\hline KPIs & $\begin{array}{r}\text { Emissions of } \\
\text { Greenhouse } \\
\text { Gases }(\mathbf{t})\end{array}$ & $\begin{array}{r}\text { Water Con- } \\
\text { sumption }\left(\mathbf{m}^{\mathbf{3}}\right)\end{array}$ & $\begin{array}{r}\text { Waste Pro- } \\
\text { duction }(\mathbf{t})\end{array}$ \\
\hline Actual performance & 0.01 & 4116.00 & 308.57 \\
Benchmark & 0.01 & 1873.07 & 214.04 \\
\hline
\end{tabular}

Individual environmental KPIs together with their benchmarks can be visually integrated in an AMOEBA graph. In Figure 2, the benchmark is considered $100 \%$ and the actual performance of company " $\mathrm{H}$ " is relative to the benchmark. Users can see at a glance that Water Consumption significantly exceeds its benchmark and is therefore the weakest point in the environmental performance of this particular company.

The graphic presentation of environmental KPIs in the context of their benchmarks makes the model outputs clear and easy to understand because it is obvious at a glance which KPIs effect environmental performance positively and negatively. 


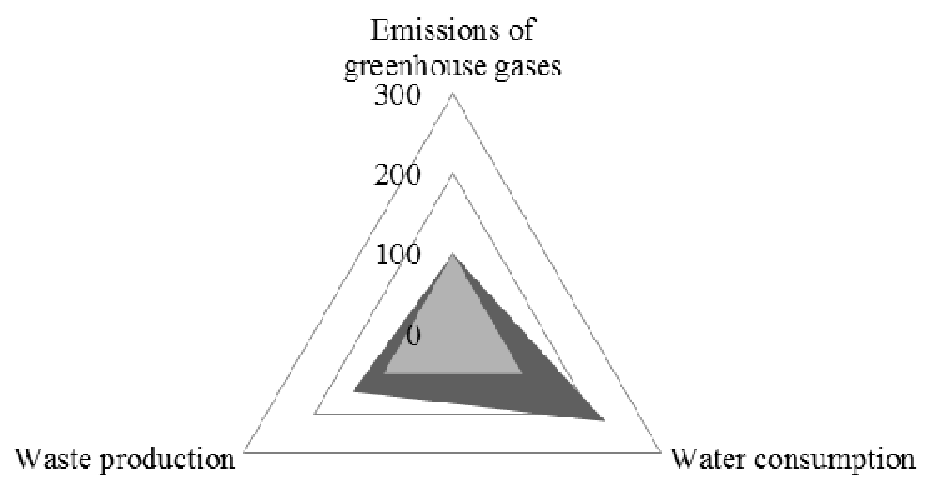

Actual performance (\%) $\quad$ Benchmark $(\%)$

Fig. 2. Environmental performance of company "H"

The model outputs allow users to identify weaknesses in performance and to quantify performance gaps, for which reason the environmental performance benchmarking model can serve its users as a basis for decision-making and performance management. Information about environmental performance should be an integral part of corporate reporting $[23,24]$.

\section{Conclusions}

A framework for an environmental performance benchmarking model was proposed in this paper. Data Envelopment Analysis is the benchmarking method used in the model. This approach has the following advantages: the performance of the company is expressed in one number given by the coefficient of technical efficiency, the model quantifies necessary improvements - performance gaps and also identifies the "best practice" in the particular industry. Information then becomes an important source material for quality decisions by the management. The weakness of the model is that performance is relative, and adding another company to the analyzed group will change the environmental performance.

Acknowledgements. This paper is supported by grant no. 14-23079S Measuring Corporate Sustainability in Selected Sectors from the Czech Science Foundation.

\section{References}

1. Lankoski, L.: Environmental and Economic Performance. The Basic Links. In: Schaltegger, S., Wagner, M. (eds.) Managing Business Case for Sustainability, pp. 82-106. Greenleaf Publishing, Sheffield (2006) 
2. ISO 14031:2013 Environmental management - Environmental performance evaluation - Guidelines

3. Russo, M.V., Fouts, P.A.: A resource-based perspective on corporate environmental performance and profitability. Academy of management Journal 40, 534-559 (1997)

4. Kirchhoff, S.: Green business and blue angels: a model of voluntary overcompliance with asymmetric information. Environmental and Resource Economics 15, 403-420 (2000)

5. Feddersen, T.J., Gilligan, T.W.: Saints and markets: activists and the supply of credence goods. Journal of Economics and Management Strategy 10, 149-171 (2001)

6. Fisman, R., Heal, G., Nair, V.B.: A Model of Corporate Philanthropy. New York, Columbia University (2008),

http: //d1c25a6gwz7q5e.cloudfront. net/papers/1331.pdf

7. Horváthová, E.: Does environmental performance affect financial performance? A metaanalysis. Ecological Economics 70, 52-59 (2010)

8. Rothenberg, S., Schenck, B., Maxwell, J.: Lessons from benchmarking environmental performance at automobile assembly plants. Benchmarking: An International Journal 12, 5-15 (2005)

9. Matthews, D.H.: Environmental management systems for internal corporate environmental benchmarking. Benchmarking: An International Journal 10, 95-106 (2003)

10. ISO 14001:2004 Environmental management systems - Requirements with guidance for use

11. Tokos, H., Pintarič, Z.N., Krajnc, D.: An integrated sustainability performance assessment and benchmarking of breweries. Clean Technologies and Environmental Policy 14, 173-193 (2012)

12. Aigner, D., Lovell, C.A.K., Schmidt, P.: Formulation and estimation of stochastic frontier production function models. Journal of Econometrics 6, 21-37 (1977)

13. Meeusen, W., van den Broeck, J.: Efficiency estimation from Cobb-Douglas production functions with composed error. International Economic Review 8, 435-444 (1997)

14. Charnes, A., Cooper, W., Rhodes, E.: Measuring the efficiency of decision-making units. European Journal of Operational Research 2, 429-444 (1978)

15. Zhu, J.: Quantitative Models for Performance Evaluation and Benchmarking: DEA with Spreadsheets. Springer, Boston (2009)

16. Post, T., Spronk, J.: Performance benchmarking using interactive data envelopment analysis. European Journal of Operational Research 115, 472-487 (1999)

17. Kocmanová, A., Klímková, M., Karpíšek, Z.: The Construction of Environmental Indicators for Determination of Performance of ESG Indicators to Support Decision-Making of investors. Business: Theory and Practice 13, 333-342 (2012)

18. Kocmanová, A., Němeček, P., Dočekalová, M.: Environmental, Social and Governance (ESG) Key Performance Indicators for Sustainable Reporting. In: 7th International Scientific Conference, pp. 655-663. Gediminas Technical University, Vilnius (2012)

19. Hřebíček, J., Piliar, F., Soukopová, J., Štencl, M., Trenz, O.: Corporate Key Performance Indicators for Environmental Management and Reporting. Acta Universitatis Agriculturaeet Silviculturae Mendelianae Brunensis 59, 99-108 (2011)

20. Elkington, J.: Cannibals with Forks: The Triple Bottom Line of the 21st Century. New Society Publishers, Stoney Creek (1998)

21. Kocmanová, A., Dočekalová, M.: Construction of the economic indicators of performance in relation to environmental, social and corporate governance (ESG) factors. Acta Universitatis Agriculturaeet Silviculturae Mendelianae Brunensis 60, 141-149 (2012) 
22. Chvátalová, Z., Kocmanová, A., Dočekalová, M.: Corporate Sustainability Reporting and Measuring Corporate Performance. In: 9th IFIP WG 5.11 International Symposium on Environmental Software Systems, pp. 245-254. ISESS, Brno (2011)

23. Hřebíček, J.: Voluntary Reporting in the Czech Republic and Indicators of Sustainable Development. Linde, Praha, pp. 257-264 (2009)

24. Hřebíček, J., Soukopová, J.: Voluntary Company Assessment Report on the Linkages between Environment, Economy and Society. Ministry of Environment of the Czech Republic, Praha (2011) (in Czech) 